\title{
Respon Pertumbuhan dan Konsentrasi Klorofil-a pada Kultur Mikroalga Chaetoceros gracilis terhadap Perbedaan Suhu Kultur
}

\author{
Ni Luh Putu Citra Adriyanti ${ }^{\mathrm{a}}$, I Wayan Arthana ${ }^{\mathrm{a}}$, Widiastuti ${ }^{*}$ \\ ${ }^{a}$ Program Studi Ilmu Kelautan, Fakultas Kelautan dan Perikanan, Universitas Udayana, Bali, Indonesia \\ *Corresponding author, email:widiastutikarim@unud.ac.id
}

\section{ARTICLE INFO}

\section{ABSTRACT}

\section{Article history:}

Received: September $19^{\text {th }} 2020$

Received in revised form: October $20^{\text {th }} 2020$

Accepted: November $25^{\text {th }} 2020$

Available online: February $28^{\text {th }} 2021$
Keywords:

Chaetoceros gracilis

Chlorophyll- $a$

Growth rate

Growth trends

Temperature

\begin{abstract}
Microalgae Chaetoceros gracilis is widely used in aquaculture. Its culture highly depends on environmental factors, particularly temperature. This study aimed to examine the growth rate and its growth trend of $C$. gracilis, also chlorophyll- $a$ concentration at different temperature. cultures were incubated at 25,30 dan $34^{\circ} \mathrm{C}$ for seven days using $\mathrm{Na}$ media with three replicates. Cell density was counted every day using a hemocytometer, whereas the concentration of chlorophyll$a$ was measured in spectrophotometry method. The differences in growth rates and chlorophyll- $a$ concentration at different temperatures were statistically analyzed with One-Way ANOVA. The difference variables were further tested with the Tukey HSD test. The trend of the growth and duration of $C$. gracilis at 25 and $30{ }^{\circ} \mathrm{C}$ were similar, with the lag phase (three days), logarithmic (two days), stationary (one day), and declination (one day), in contrast at $34{ }^{\circ} \mathrm{C}$ that had lower duration and missed the stationary phase. The growth rates of microalgae $C$. gracilis was insignificantly differences at the temperature of 25 and $30{ }^{\circ} \mathrm{C}(0.7 \pm 0.05 \mathrm{cell} / \mathrm{ml} / \mathrm{day})$, but significantly lower at $34^{\circ} \mathrm{C}(0.28 \pm 0.03 \mathrm{cell} / \mathrm{ml} /$ day $)$. The chlorophyll- $a$ concentrations at the temperature of 25 and $30{ }^{\circ} \mathrm{C}$ were not significantly different $(0.37 \pm 0.05$ and $0.39 \pm 0.03 \mathrm{mg} / \mathrm{l})$, while the chlorophyll- $a$ concentration at $34{ }^{\circ} \mathrm{C}$ was significantly lower $(0.26 \pm 0.04 \mathrm{mg} / \mathrm{l})$. This result indicates the high temperature $\left(34{ }^{\circ} \mathrm{C}\right)$ inhibited the metabolism of $C$. gracilis as shown by doubling times that slower ( 2.5 day) than the temperature at 25 and $30^{\circ} \mathrm{C}$. It is concluded that the optimum temperatures for the C. gracilis were 25 and $30^{\circ} \mathrm{C}$, where as $34^{\circ} \mathrm{C}$ was the inhibited temperature.
\end{abstract}

2021 JMRT. All rights reserved.

\section{Pendahuluan}

Mikroalga merupakan organisme mikroskopis bersel tunggal yang dapat hidup diseluruh perairan dan bersifat autotrof karena memiliki pigmen klorofil untuk melakukan fotosintesis (Endrawati dan Riniatsih, 2013; Pacheco et al., 2015). Mikroalga dapat tumbuh dan bertahan hidup pada berbagai lingkungan baik di alam bebas seperti air bersih maupun air kotor yang terdapat limbah, maupun dengan kondisi lingkungan yang diatur sedemikan rupa (Mata et al., 2009). Peran mikroalga sebagai produsen primer di perairan karena dimanfaatkan oleh biota lainnya dalam piramida makanan (Pangabean, 2007). Menurut Mata et al. (2009), spesies mikroalga yang baru diteliti dan dipelajari tercatat kurang lebih 30.000 jenis, salah satu jenisnya yaitu Chaetoceros gracilis. Mikroalga $C$. gracilis terklasifikasi ke dalam kelas Bacillariophyceae; ordo Chaetocerotanae incertae sedis; famili Chaetocerotaceae dan genus Chaetoceros (Schutt, 1895). Mikroalga ini dibudidayakan dan dimanfaatkan sebagai pakan alami untuk larva udang dan kerang (Rukmana et al., 2017; Likun et al., 2014; Parrish and Wangersky, 1990; Nhu, 2004) dan penelitian terus dilakukan karena berpotensi sebagai biofuel dengan kandungan lipid yang cukup tinggi dibandingkan dengan organisme tingkat tinggi lainnya melalui proses gasifikasi dan pirolisis (Handayani dan Ariyanti, 2012; Randrianarison dan Ashraf, 2017; Tokushima et al., 2016).

Keberhasilan kultur mikroalga dipengaruhi oleh beberapa faktor lingkungan, antara lain: suhu, cahaya, $\mathrm{pH}$, salinitas, $\mathrm{CO}_{2}$ dan ketersedian nutrien (Randrianarison and Ashraf, 2017). Diantara faktor-faktor pembatas pertumbuhan tersebut, suhu memiliki peran yang sangat penting dalam proses metabolisme sehingga dapat mempengaruhi kandungan biomassa ataupun pertumbuhan dari mikroalga (Likun et al., 2014; Rai dan Rajashekhar, 2014; Chaisutyakorn et al., 2017). Hasil penelitian Arifah (2014) menyatakan, semakin rendah suhu maka semakin tinggi kandungan lipid yang dimiliki mikroalga, namun bila semakin tinggi suhu maka laju pertumbuhan dan biomassa mikroalga semakin tinggi dan menyebabkan fase kematian terjadi semakin cepat. Hasil penelitian lainnya yaitu Endrawati dan Riniatsih (2013) menunjukkan bahwa kepadatan tertinggi Nannochloropsis oculata sebesar $81,9 \mathrm{mg} / \mathrm{ml}$ terdapat pada suhu $28{ }^{\circ} \mathrm{C}$, sedangkan kadar total lipid tertinggi yaitu 52,62\% pada suhu $33{ }^{\circ} \mathrm{C}$. Hasil uji konsentrasi klorofil- $a$, protein dan karbohidrat pada Cheatoceros simplex mengindikasikan bahwa selain sensitif terhadap suhu, pertumbuhan mikroalga juga dipengaruhi oleh konsentrasi nitrat 
dan silikat dimana diperoleh konsentrasi klorofil- $a$ tertinggi yaitu pada suhu $20{ }^{\circ} \mathrm{C}(1,57 \pm 0,05 \mathrm{pg} / \mathrm{sel})$ dengan konsentrasi Nitrat $\left[\mathrm{NO}_{3}{ }^{-}\right]$yaitu $2205 \mu \mathrm{M}$ dan konsentrasi Silikat $\left[\mathrm{SiO}_{3}{ }^{2-}\right]$ yaitu 265 $\mu \mathrm{M}$, kadar protein dan karbohidrat tertinggi didapatkan pada suhu $25{ }^{\circ} \mathrm{C}$ yaitu berturut-turut $4,48 \pm 0,17 \mathrm{pg} / \mathrm{sel}$ dan $0,78 \pm 0,03 \mathrm{pg} / \mathrm{sel}$ (Hemalatha et al., 2012). Kandungan pigmen klorofil c1 dan c2 pada $C$. gracilis lebih tinggi pada suhu $25{ }^{\circ} \mathrm{C}(138 \pm 7 \mu \mathrm{g} \mathrm{m} / \mathrm{L})$ daripada suhu $30{ }^{\circ} \mathrm{C}(80 \pm 5 \mu \mathrm{g} \mathrm{m} / \mathrm{L})$, sedangkan diadinoxanthin mengalami hal sebaliknya (Nagao et al., 2020). Menurut Mortensen et al., 1988), C. gracilis tumbuh baik pada suhu $32{ }^{\circ} \mathrm{C}$ dengan penambahan nutrien silikat $10 \%$ dibandingkan pada suhu 18,22 dan $28^{\circ} \mathrm{C}$ didapatkan kepadatan sel tertingi yaitu $6,13 \times 106$ $\mathrm{sel} / \mathrm{ml}$, namun pada suhu $32^{\circ} \mathrm{C}$ pertumbuhan $C$. gracilis menjadi kurang stabil. Sementara itu Halac et al., (2010) dengan pemaparan UVR dan pemberian suhu kultur 18 dan $23^{\circ} \mathrm{C}$ pada diatom $C$. garcilis dan Thalassiosira weissflogii menunjukkan kinerja fotosintesis lebih baik pada suhu tinggi $\left(23^{\circ} \mathrm{C}\right)$. UVR memberi pengaruh penghambatan pertumbuhan dengan rata-rata penghambatan $C$. garcilis $\left(18{ }^{\circ} \mathrm{C}\right.$ sebesar $29,8 \pm 3,7$ dan $23{ }^{\circ} \mathrm{C}$ sebesar $15,9 \pm 3,9)$ dan $T$. weissflogii $\left(18{ }^{\circ} \mathrm{C}\right.$ sebesar $46,1 \pm 5,4$ dan $23{ }^{\circ} \mathrm{C}$ sebesar $36,7 \pm 6,6$ ). Berbagai perbedaan respon pertumbuhan terhadap suhu kultur dapat menyebabkan ketidakpastian dalam menentukan suhu kultur yang tepat yang digunakan untuk optimalisasi kultur mikroalga $C$. gracilis. Oleh karena itu, penelitian ini dilakukan untuk mengetahui tren pertumbuhan kultur dan laju pertumbuhan, serta kandungan klorofil $-a$ mikroalga $C$. gracilis terhadap suhu kultur yang berbeda.

\section{Metodologi}

\subsection{Waktu dan Tempat}

Penelitian dilaksanakan pada Bulan Pebruari 2020. Kultur mikroalga bertempat di Laboratorium Ilmu Kelautan Fakultas Kelautan dan Perikanan Universitas Udayana dan uji klorofil- $a$ bertempat di UPT. Laboratorium Analitik, Universitas Udayana.

\subsection{Prosedur Penelitian}

\subsubsection{Sterilisasi Alat dan Bahan}

Sterilisasi dilakukan pada alat seperti toples kaca, mikropipet, erlenmeyer, dan tabung reaksi. Sementara itu, bahan yang disterilisasi adalah air laut yang telah disaring dan media pertumbuhan (media $\mathrm{Na}$ ). Komposisi media $\mathrm{Na}$ yang digunakan dalam kultur C. gracilis sesuai dengan Eda (1989) (Tabel 1).

Tabel 1. Komposisi Media Na

\begin{tabular}{lccc}
\hline \multicolumn{1}{c}{ Bahan } & $\begin{array}{c}\text { Konsentrasi } \\
(\text { gr })\end{array}$ & $\begin{array}{c}\text { Pelarut } \\
(\mathbf{m l})\end{array}$ & $\begin{array}{c}\text { Konsentrasi } \\
\text { untuk Media } \\
(\mathbf{m l} / \mathbf{l})\end{array}$ \\
\hline $\mathrm{NaNO}_{3}$ & 20 & 200 & 3 \\
$\mathrm{NaHPO}_{4}$ & & & \\
$-\quad \mathrm{Na}_{2}$ & 2,8 & & \\
$\mathrm{HPO}_{4} 12$ & & & \\
$\quad \mathrm{H}_{2} \mathrm{O}$ & & 200 & 1 \\
$-\quad \mathrm{NaHCO}$ & 2,8 & & \\
$-\quad \mathrm{EDTA} 2$ & 3,62 & & \\
$\quad \mathrm{Na}$ & & 200 & 1 \\
$\mathrm{Na} \mathrm{SiO}_{3}$ & 1 & 200 & 1 \\
$\mathrm{FeCl}$ & 20 & 500 & 1 \\
$\mathrm{Vitamin} \mathrm{B1}$ & 0,2 & 200 & 1 \\
$\mathrm{Vitamin} \mathrm{B12}$ & 0,1 & 500 & 1 \\
Vitamin H & 0,1 & & \\
\hline
\end{tabular}

\subsubsection{Persiapan Media Kultur}

Komposisi media Na yang digunakan dalam kultur C. gracilis sesuai dengan Tabel 1. Air laut steril yang digunakan sebagai media kultur pada masing-masing sampel yaitu sebanyak 81 dan diberi media Na sebanyak 8 ml/1 (Eda, 1989). Kondisi lingkungan kultur yaitu salinitas $35 \mathrm{ppt}$ dan $\mathrm{pH}$ 7. Media kultur diberi aerator sebagai sumber oksigen (Sartika et al., 2014).

\subsubsection{Kultur Mikroalga}

Inokulan mikroalga tersebut didapatkan dari Balai Besar Riset Budidaya Laut dan Penyuluhan Perikanan (BBRBLPP) Gondol, Bali. Sebelum diberi perlakuan suhu, inokulan mikroalga dibuat stok kultur. Setelah pembuatan stok kultur, mikroalga kemudian dimasukan kembali ke media kultur dan diberi perlakuan suhu yaitu 25,30 , dan $34{ }^{\circ} \mathrm{C}$.

\subsubsection{Rancangan Penelitian}

Masing-masing mikroalga dikultur pada suhu yang berbeda yaitu suhu $25{ }^{\circ} \mathrm{C}$ sebagai suhu kontrol, suhu $30{ }^{\circ} \mathrm{C}$ merupakan batas kisaran optimal suhu kultur C. gracilis (Mortensen et al., 1988; Kawaroe et al., 2010). Suhu $34{ }^{\circ} \mathrm{C}$ merupakan kisaran batas toleransi suhu yang dimiliki oleh C. gracilis (Kawaroe et al., 2010). Masing-masing perlakuan dilakukan sebanyak 3 ulangan (gambar 1). Inokulan yang telah dimasukan ke dalam masing-masing media kultur, ditutup dengan plastic wrap agar tidak terkontamisasi dan diberi cahaya lampu TL 40 watt dengan panjang cahaya 1000-2000 lux. Pemeliharaan kultur ini dilakukan selama 7 hari.

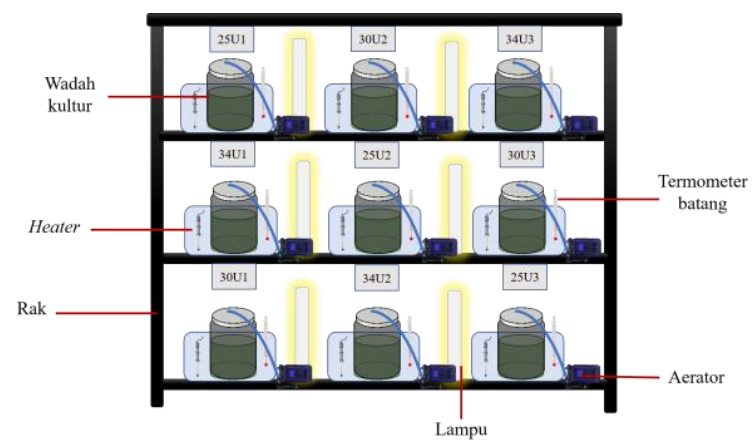

Gambar 1. Perlakuan suhu yang diberikan

\subsubsection{Menghitung Kepadatan Sel C. gracilis}

Kepadatan sel mikroalga dilakukan dengan cara mengambil 1 ml sampel dengan mikropipet, kemudian dimasukan pada hemositometer dan dilihat dibawah mikroskop dengan perbesaran lensa objektif 10 kali. Perhitungan kepadatan sel dilakukan setiap hari dengan Persamaan 1 (LeGresley dan McDermott, 2010).

Kepadatan sel $=\frac{\text { jumlah sel dalam } 4 \text { kotak }}{\text { jumlah kotak }} \times 10^{4}(\mathrm{sel} / \mathrm{ml})$

\subsubsection{Laju Pertumbuhan Sel C. gracilis}

Laju pertumbuhan merupakan laju peningkatan atau pertambahan jumlah sel mikroalga di dalam kultur pada waktu tertentu (Andersen, 2005). Laju pertumbuhan sel C. gracilis dihitung pada fase logaritmik berdasarkan Guillard (1973), dapat dilihat pada Persamaan 2.

$\mu=\frac{\ln \left(N_{t} / N_{0}\right)}{\Delta t}$

Dimana $\mu$ merupakan laju pertumbuhan (sel/ml/hari); $\mathrm{N}_{\mathrm{t}}$ merupakan kepadatan akhir sel pada waktu ke-t (sel/ml); $\mathrm{N}_{0}$ merupakan kepadatan sel awal (sel/ml); $\Delta \mathrm{t}$ merupakan interval waktu (hari). 


\subsubsection{Waktu Penggandaan (doubling time)}

Waktu penggandaan $(k)$ merupakan waktu yang diperlukan oleh mikroalga untuk mengandakan sel per unit waktu (hari) (Andersen, 2005) ditunjukkan pada Persamaan 3.

$$
k=\frac{\mu}{0,6931}
$$

\subsubsection{Uji Kandungan Klorofil-a}

Kandungan klorofil- $a$ dihitung berdasarkan Ihsan et al. (2017) pada Persamaan 4.

Klorofil $-a(\mathrm{mg} / \mathrm{l})=\frac{c_{a} \times v_{a}}{v \times d}$

Dimana $\mathrm{C}_{\mathrm{a}}$ merupakan nilai absorbansi $(11,85 \mathrm{x}$ E664) - $(1,54 \mathrm{x}$ E647) - (0,08 x E630); E merupakan panjang gelombang yang digunakan pada spektrofotometer; $\mathrm{V}_{\mathrm{a}}$ merupakan volume aseton $(\mathrm{ml})$; v merupakan volume sampel yang disaring $(\mathrm{ml})$ dan $\mathrm{d}$ merupakan diameter cuvet.

\subsection{Analisa Data}

Pengaruh perbedaan suhu kultur terhadap laju pertumbuhan, dan konsentrasi klorofil- $a$ dianalisa secara statistik dengan uji OneWay ANOVA (Fowler et al., 1998) dengan asumsi bahwa sampel dipengaruhi oleh varian yang sama atau independen dan dilakukan uji normalitas dan uji homogenitas untuk mengetahui data terdistribusi secara normal dan bersifat homogen $(\mathrm{P}>0,05)$. Uji One-Way ANOVA dengan taraf kepercayaan 95\% dan uji lanjutan dengan uji Tukey HSD untuk mengetahui perbedaan antar variabel.

\section{Hasil dan Pembahasan}

\subsection{Pertumbuhan Kultur Mikroalga C. gracilis}

Kepadatan sel mikroalga $C$. gracilis pada masing-masing suhu kultur ditampilkan pada Gambar 2. Kepadatan sel mikroalga $C$. gracilis berbeda pada suhu kultur yang berbeda sehingga memberikan tren pertumbuhan yang berbeda pula. Tren pertumbuhan suhu 25 dan $30{ }^{\circ} \mathrm{C}$ relatif sama yaitu mengalami durasi fase lag atau adaptasi yang sama yaitu hari 0-3, kemudian mengalami peningkatan jumlah sel secara eksponensial (fase logaritmik) selama tiga hari yaitu pada hari ke 3-5. Kemudian kedua suhu kultur memasuki fase stationer yaitu fase laju pertumbuhan mikroalga mulai menurun dan sel tidak mengalami pertumbuhan lagi pada hari ke 5-6, kemudian mengalami fase kematian pada hari ke 6-7. Tren pertumbuhan tersebut berbeda dengan kultur mikroalga $C$. gracilis pada suhu $34{ }^{\circ} \mathrm{C}$ dimana fase lag berlangsung selama 4 hari, fase logaritmik terjadi pada hari ke 4-5, kemudian disusul fase kematian pada hari ke 5-7 tanpa fase stationer.

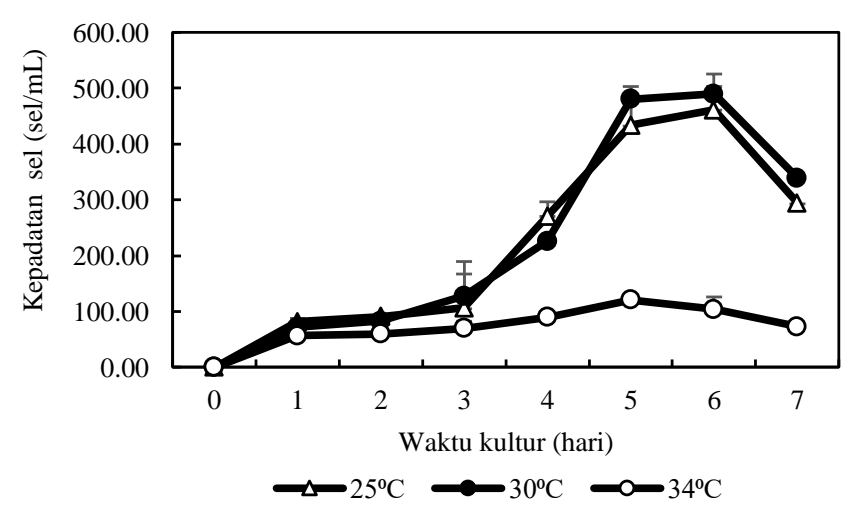

Gambar 2. Kepadatan Sel C. gracilis yang dikultur pada pada media dengan suhu yang berbeda
Suhu merupakan salah satu faktor lingkungan yang paling berpengaruh pada pertumbuhan mikroalga, termasuk $C$. gracilis (Renaud et al., 2001; Likun et al., 2014; Hemalatha et al., 2012; Rai and Rajashekhar, 2014). Seluruh inokulum C. gracilis dengan suhu yang berbeda-beda memasuki fase lag atau adaptasi untuk proses menyesuaikan diri akibat adanya berbedaan kodisi lingkungan. Fase adaptasi $C$. gracilis pada suhu 25 dan $30{ }^{\circ} \mathrm{C}$ berlangsung selama 3 hari, sedangkan suhu $34{ }^{\circ} \mathrm{C}$ terjadi 4 hari. Perbedaan lama fase adaptasi karena C. gracilis pada suhu $34{ }^{\circ} \mathrm{C}$ belum mampu beradaptasi pada suhu tersebut sehingga memerlukan waktu yang lebih lama untuk menyesuaikan sel dengan kondisi kultur yang baru. Pada suhu kultur $34{ }^{\circ} \mathrm{C}$, sel-sel $C$. gracilis bersifat sensitif sehingga tidak dapat segera beradaptasi dengan kondisi. Hal tersebut sesuai dengan pernyataan Arfah et al. (2019) dan Kurniawan et al. (2017), ketika kultur mikroalga memasuki fase lag, organisme cenderung tidak terjadi pembelahan sel, hal ini dikarenakan energi yang dimiliki banyak dimanfaatkan untuk mempertahankan diri pada lingkungan kultur baru sehingga populasi tidak berubah. Hasil penelitian Haris (2012), Scenedesmus sp. dikultur dengan suhu 15, 20, 25 dan $30{ }^{\circ} \mathrm{C}$ tidak menunjukan fase adaptasi karena sel mampu beradaptasi kurang dari 24 jam. Sementara itu, Endrawati dan Riniatsih (2013) menyatakan Nannochloropsis oculata memerlukan waktu lebih lama untuk penyesuaian diri pada suhu $33{ }^{\circ} \mathrm{C}$ dibandingkan suhu 18,23 dan $28{ }^{\circ} \mathrm{C}$. Hal tersebut menunjukkan kemampuan masingmasing sel beradaptasi pada kondisi kultur baru berbeda-beda yang mengakibatkan durasi atau waktu adaptasi dapat berlangsung cepat ataupun lama (Rudiyanti, 2011) dan bila mikroalga tidak mampu bertahan pada kondisi suhu tersebut sel-sel mikroalga akan mati (Prayitno, 2016). Saat inokulum menerima kondisi lingkungan baru, aktivitas enzim dalam $C$. gracilis juga ikut berubah agar proses asimilasi karbon tetap bisa berjalan saat fotosintesis, maka ketika terjadi kenaikan suhu menyebabkan terganggunya proses pertumbuhan C. gracilis (Likun et al., 2014).

Fase logaritmik kultur suhu 25 dan $30{ }^{\circ} \mathrm{C}$ terlihat sangat jelas dibandingkan suhu $34{ }^{\circ} \mathrm{C}$ (Gambar 2). Pada suhu 25 dan $30{ }^{\circ} \mathrm{C}$ fase logaritmik berlangsung selama dua hari dengan kepadatan tertinggi yaitu $434 \times 10^{4} \mathrm{sel} / \mathrm{ml}$ dan $481 \times 10^{4} \mathrm{sel} / \mathrm{ml}$, sedangkan suhu $34^{\circ} \mathrm{C}$ memperoleh $121 \times 10^{4} \mathrm{sel} / \mathrm{ml}$ selama satu hari. Fase ini, C. gracilis sangat baik untuk dipanen karena sel dalam kodisi yang optimal. Perbedaan jumlah kepadatan sel yang dihasilkan karena $C$. gracilis sulit melakukan metabolisme pada suhu yang terlalu tinggi $\left(34^{\circ} \mathrm{C}\right)$, sehingga pembelahan sel tidak bisa berjalan secara maksimal dan kepadatan yang dihasilkan tidak sebanyak pada suhu kultur 25 dan $30{ }^{\circ} \mathrm{C}$. Hasil penelitian Adenan et al. (2013) yaitu kepadatan sel $C$. calcitrans dan Chlorella sp. yang dikultur pada suhu berbeda menunjukan tingkat kepadatan sel berbeda, pada $C$. calcitrans diperoleh $210 \times 10^{6} \mathrm{sel} / \mathrm{ml}$ pada suhu $30{ }^{\circ} \mathrm{C}$, sedangkan Chlorella sp. suhu $25{ }^{0} \mathrm{C}$ sebesar $290 \times 10^{6} \mathrm{sel} / \mathrm{ml}$ karena spesies mikroalga tersebut memiliki kemampuan toleransi kisaran suhu pertumbuhan yang berbeda. Menurut Parrish dan Wangersky (1990); Tokushima et al. (2016) dan Nagao et al. (2020) bahwa kisaran suhu yang baik untuk pertumbuhan $C$. gracilis adalah suhu $15-35{ }^{\circ} \mathrm{C}$, namun optimum pada suhu $24-30{ }^{\circ} \mathrm{C}$. Suhu yang tinggi mengakibatkan enzim yang digunakan dalam proses kimia mengalami kerusakan atau denaturasi, sedangkan suhu yang terlalu rendah kerja enzim akan berjalan lambat (Endrawati dan Riniatsih, 2013), dimana enzim memiliki peran untuk asimilasi karbon dalam proses fotosintesis (Likun et al., 2014).

Pertumbuhan $C$. gracilis cenderung sudah tidak mengalami pertumbuhan atau fase stasioner pada kultur suhu $25-30{ }^{\circ} \mathrm{C}$ pada hari ke-6 (Gambar 2) kandungan media pertumbuhan sudah sangat berkurang akibat terserap oleh $C$. gracilis ketika sel mengalami puncak pertumbuhan karena media pertumbuhan hanya diberi saat 
awal kultur. Sementara itu, pada suhu $34{ }^{0} \mathrm{C}$ tidak terlihat mengalami fase stasioner karena jumlah sel $C$. gracilis lebih banyak mati sebagai akibat sel tidak mampu bertahan lama pada suhu tinggi sehingga grafik pertumbuhan langsung menunjukan fase kematian. Selain itu, suhu yang tinggi membuat $C$. gracilis mempercepat aktivitas sel seperti menyerap nutrien sehingga nutrien menjadi cepat habis untuk bahan fotosintesis. Hasil penelitian serupa juga menunjukan Scenedesmus sp. yang diberi empat suhu berbeda selama 10 hari semuanya tidak mengalami fase stasioner dikarenakan nutrien yang menjadi sumber energi sudah habis (Haris, 2012). Menurut Converti et al. (2009), variasi suhu dan penurunan konsentrasi nitrat sebagai unsur hara pada media pertumbuhan mempengaruhi kehidupan mikroalga. Bangun et al. (2015) menyatakan pola pertumbuhan yang ditunjukan oleh mikroalga tidak selalu sama. Pertumbuhan diatom dipengaruhi oleh berbagai faktor lingkungan seperti suhu, salinitas, $\mathrm{CO}_{2}$ dan nutrisi (Kawaroe et al., 2010). Peningkatan suhu bisa menyebabkan pertumbuhan yang cepat namun menyebabkan berkurangnya waktu generasi kultur mikroalga (Hemalatha et al., 2012). Adenan et al., (2013) menyatakan peningkatan suhu yang terlalu tinggi memicu pembelahan sel lebih cepat, karena perubahan aktivitas metabolisme sel sebagai respon terhadap tekanan lingkungan, tetapi waktu hidupnya menjadi lebih singkat.

Fase terakhir yang dialami $C$. gracilis adalah fase deklinasi. Pada fase ini ditandai dengan kepadatan mikroalga terus menurun, fase deklinasi suhu $34{ }^{\circ} \mathrm{C}$ terjadi lebih cepat pada hari ke 6 , kemudian diikuti oleh suhu 25 dan $30^{\circ} \mathrm{C}$ yang terjadi pada hari ke 7. Terjadinya fase deklinasi karena nutrisi pada media tumbuh habis dimanfaatkan oleh C. gracilis. Menurut Ningsih et al. (2017) dan Hadiyanto dan Azim (2012), kepadatan mikroalga menurun ditandai dengan jumlah sel tidak bertambah lagi akibat mengalami kematian. Kekurangan nutrien dalam waktu yang lama menyebabkan pertumbuhan mikroalga akan menurun, hal sebaliknya juga dapat terjadi bila kelebihan unsur hara menyebabkan keracunan meskipun pada awalnya biomassa sel meningkat (Christiani et al., 2017).

\subsection{Laju Pertumbuhan dan Kandungan Klorofil-a}

Rerata laju pertumbuhan, konsentrasi klorofil-a dan waktu penggandaan ditunjukkan pada Tabel 2. Berdasarkan hasil uji One-Way ANOVA, laju pertumbuhan $C$. gracilis berbeda signifikan pada suhu kultur yang berbeda (Tabel 2), dimana laju pertumbuhan pada suhu 25 dan $30^{\circ} \mathrm{C}$ lebih tinggi secara signifikan $(\mathrm{df}=2 ; \mathrm{P}=0,005)$, tetapi laju pertumbuhan pada suhu 25 dan $30^{\circ} \mathrm{C}$ tidak berbeda signifikan. Waktu penggandaan sel $C$. gracilis pada suhu $34{ }^{\circ} \mathrm{C}$ memerlukan waktu paling lama diantara ketiga suhu kultur yaitu 2,5 hari, sementara suhu 25 dan $30{ }^{\circ} \mathrm{C}$ relatif memerlukan waktu penggadaan sel lebih singkat yaitu 1 hari (Tabel 2).

Tabel 2. Rerata laju pertumbuhan $(\mu)$, waktu penggandaan $(k)$ dan konsentrasi klorofil- $a$ pada kultur $C$. gracilis dengan suhu berbeda (mean \pm std)

\begin{tabular}{cccc}
\hline $\begin{array}{c}\text { Suhu } \\
\left({ }^{\mathbf{C}} \mathbf{C}\right)\end{array}$ & $\begin{array}{c}\text { Laju } \\
\text { Pertumbuhan } \\
(\mathbf{s e l} / \mathbf{m l} / \text { hari) }\end{array}$ & $\begin{array}{c}\text { Waktu } \\
\text { penggandaan } \\
\text { sel (per hari) }\end{array}$ & $\begin{array}{c}\text { Kandungan } \\
\text { klorofil- } \boldsymbol{a} \\
(\mathbf{m g} / \mathbf{l})\end{array}$ \\
\hline 25 & $0,7 \pm 0,05$ & $0,99 \pm 0,07$ & $0,37 \pm 0,05$ \\
30 & $0,66 \pm 0,01$ & $1,05 \pm 0,02$ & $0,39 \pm 0,03$ \\
34 & $0,28 \pm 0,03$ & $2,54 \pm 0,04$ & $0,26 \pm 0,04$ \\
\hline
\end{tabular}

Hasil yang sama ditunjukkan pada kandungan klorofil- $a$ yang menunjukan bahwa perbedaan suhu berpengaruh signifikan terhadap kandungan klorofil- $a$ dimana konsentrasi klorofil- $a$ pada suhu $25^{\circ} \mathrm{C}$ secara signifikan sama tingginya dengan suhu $30^{\circ} \mathrm{C}$ $(\mathrm{P}=0,014)$, namun konsentrasi klorofil- $a$ pada suhu $34^{\circ} \mathrm{C}$ lebih rendah dari suhu 25 dan $30^{\circ} \mathrm{C}$ (Tabel 2).

Laju pertumbuhan $C$. gracilis lebih lambat pada suhu $34{ }^{\circ} \mathrm{C}$ $(0,28 \pm 0,03 \mathrm{sel} / \mathrm{ml} / \mathrm{hari})$ dibandingkan pada 25 dan $30{ }^{\circ} \mathrm{C}$ karena proses metabolisme sel $C$. gracilis terganggu pada suhu tinggi. Aktivitas pertukaran karbon pada proses metabolisme dengan bantuan enzim Rubisco (Ribulosa 1,5 carboxylic biphosphat) menjadi terganggu, dimana salah satu faktor yang mempengaruhi kerja enzim tersebut adalah suhu (Likun et al., 2014). Sifat enzim yaitu akan bekerja dengan baik pada suhu yang optimum, bila pada suhu terlalu rendah yaitu enzim menjadi tidak aktif. Sementara itu, terjadi hal sebaliknya terjadi jika peningkatan suhu terlalu tinggi menyebabkan struktur kimia enzim rusak yang menyebabkan kerja enzim menurun ataupun terhenti (Wahjuni, 2013). Pertumbuhan mikroalga menurun tajam akibat sel menjadi stres karena kondisi lingkungan (Converti et al., 2009; Suantika et al., 2009; Kurniawan et al., 2017). Ras et al. (2013) menyatakan, suhu optimum dan batas toleransi pada mikroalga berbeda-beda sehingga mempengaruhi efisiensi produksi dari mikroalga itu sendiri. Laju pertumbuhan mikroalga yang rendah akibat dari peningkatan respirasi sel karena melakukan adaptasi untuk bertahan (Fogg and Thake, 1987). Sheehan (1998) menyatakan peningkatan suhu pertumbuhan memicu respirasi sel yang tinggi, sebagai respon terhadap perubahan aktivitas metabolisme sel sebagai respons terhadap tekanan (stres) lingkungan. Penghambatan metabolisme sel mikroalga $C$. gracilis pada suhu yang tinggi ditunjukkan pada waktu penggandaan sel, dimana dibutuhkan waktu lebih lama untuk sel menggandakan diri pada suhu $34{ }^{\circ} \mathrm{C}(2,54 \pm 0,3$ per hari $)$ dibandingkan pada suhu 25 dan $30{ }^{\circ} \mathrm{C}(0,99 \pm 0,07$ per hari). Hasil penelitian serupa menunjukan laju pertumbuhan Chaetoceros sp. pada $30{ }^{\circ} \mathrm{C}(0,87 \pm 0,01$ per hari) lebih baik dibandingkan suhu 27 ${ }^{0} \mathrm{C}$ (Renaud et al., 2001).

Selain mempengaruhi kepadatan sel dan laju pertumbuhan, suhu juga memberi nilai yang signifikan terhadap konsentrasi klorofil- $a$ pada $C$. gracilis. Klorofil berfungsi menyerap energi cahaya untuk melakukan proses fotosintesis. Rata-rata konsentrasi klorofil- $a$ tertinggi terdapat pada suhu $30{ }^{\circ} \mathrm{C}(0,390 \pm 0,030 \mathrm{mg} / \mathrm{l})$, diikuti suhu $25{ }^{\circ} \mathrm{C}(0,37 \pm 0,05 \mathrm{mg} / \mathrm{l})$ dan terendah pada suhu $34{ }^{\circ} \mathrm{C}$ $(0,259 \pm 0,039 \mathrm{mg} / \mathrm{l})$. Rendahnya konsentrasi klorofil- $a$ pada suhu kultur $C$. gracilis karena pada suhu kultur tersebut mengganggu atau menghambat metabolisme, khususnya produksi pigmen klorofil (Octhreeani et al., 2014). Namun, suhu kultur $34{ }^{\circ} \mathrm{C}$ bukan merupakan suhu letal bagi mikroalga $C$. gracilis, karena sel $C$. gracilis masih menunjukkan pertumbuhan, walaupun tidak optimal. Hal ini dapat disebabkan karena pada suhu $34^{\circ} \mathrm{C}$, energi yang dimiliki mikroalga hanya digunakan untuk mempertahankan kelangsungan hidup.

Selain mempengaruhi kepadatan sel dan laju pertumbuhan, suhu juga memberi nilai yang signifikan terhadap konsentrasi klorofil- $a$ pada $C$. gracilis. Klorofil berfungsi menyerap energi cahaya untuk melakukan proses fotosintesis. Rata-rata konsentrasi klorofil- $a$ tertinggi terdapat pada suhu $30{ }^{\circ} \mathrm{C}(0,390 \pm 0,030 \mathrm{mg} / \mathrm{l})$ dan terendah pada suhu $34{ }^{0} \mathrm{C}(0,259 \pm 0,039 \mathrm{mg} / \mathrm{l})$. Rendahnya konsentrasi klorofil- $a$ pada suhu kultur $C$. gracilis karena pada suhu kultur tersebut mengganggu/menghambat metabolisme, khususnya produksi pigmen klorofil (Octhreeani et al., 2014). Namun, suhu kultur $34{ }^{\circ} \mathrm{C}$ bukan merupakan suhu letal bagi mikroalga $C$. gracilis, karena sel $C$. gracilis masih menunjukkan pertumbuhan, walaupun tidak optimal. Hal ini dapat disebabkan karena pada suhu $34{ }^{\circ} \mathrm{C}$, energi yang dimiliki mikroalga hanya digunakan untuk mempertahankan kelangsungan hidup. Hal ini sejalan dengan hasil penelitian Hemaltha et al. (2012), pada $C$. simplex suhu kultur 20,25 dan $29{ }^{\circ} \mathrm{C}$ dan pemberian nutrien nitrat 
dan silikat dengan konsentrasi yang berbeda diketahui kepadatan sel tertinggi terdapat pada suhu $29{ }^{0} \mathrm{C}$ yaitu $23,5 \times 10^{5} \mathrm{sel} / \mathrm{ml}$, sedangkan kandungan klorofil- $a$ teringgi ditemukan pada suhu terendah yaitu $20{ }^{\circ} \mathrm{C}$ dibandingankan suhu lainnya yaitu $1,57 \times 10^{-9}$ $\pm 0,05 \mathrm{mg} / \mathrm{l}$.

\section{Kesimpulan}

Tren pertumbuhan $C$. gracilis pada suhu kultur 25 dan $30{ }^{\circ} \mathrm{C}$ cenderung sama yaitu fase adaptasi (lag), fase eksponensial, fase stasioner dan fase deklinasi dengan durasi yang relatif sama. Tren tersebut juga ditunjukkan pada suhu $34^{\circ} \mathrm{C}$ kecuali pada fase adaptasi dengan durasi yang lebih lama dari suhu kultur 25 dan 30 ${ }^{0} \mathrm{C}$ dan tidak mengalami fase stasioner.

Laju pertumbuhan tertinggi ditunjukkan pada suhu 25 dan 30 ${ }^{0} \mathrm{C}$ yang secara signifikan relatif sama $(0,7 \pm 0,05$ dan $0,66 \pm 0,01$ per hari), sedangkan laju pertumbuhan terendah yaitu pada suhu kultur $34^{\circ} \mathrm{C}$. Laju pertumbuhan sejalan dengan waktu pengandaan sel pada suhu 25 dan $30{ }^{\circ} \mathrm{C}$ yaitu \pm 1 hari, sedangkan waktu penggandaan sel pada suhu $34{ }^{\circ} \mathrm{C}$ lebih lama (2,5 hari). Konsentrasi klorofil- $a$ tertinggi terdapat pada suhu 25 dan $30{ }^{\circ} \mathrm{C}$ yang secara signifikan sama dan terendah pada suhu $34{ }^{\circ} \mathrm{C}$.

\section{Ucapan Terima Kasih}

Penulis mengucapkan terimakasih kepada Laboratorium Ilmu Kelautan Fakultas Kelautan dan Perikanan Universitas Udayana, yang telah membantu memfasilitasi pelaksanaan penelitian.

\section{Daftar Pustaka}

Adenan NS, Yusoff FM, Shariff M. 2013. Effect of salinity and temperature on the growth of diatoms and green algae. Journal of Fisheries and Aquatics Science Vol. 8 No. 2

Andersen RA. 2005. Algal culturing techniques. Elsevier Academic Press. hlm 271-274

Arfah Y, Cokrowati N, Mukhlis A. 2019. Pengaruh konsentrasi pupuk urea terhadap pertumbuhan populasi sel Nannochloropsis sp. Jurnal Kelautan Vol. 12 No. 1

Arifah S. 2014. Studi Kemampuan Nannochloropsis Sp. dan Chlorella Sp. sebagai Agen Bioremediasi Logam Berat Merkuri (Hg) dan Pengaruhnya terhadap Pertumbuhan [skripsi]. Surabaya: Fakultas Perikanan dan Kelautan Universitas Airlangga. $93 \mathrm{hlm}$.

Bangun HH, Hutabarat S, Ain C. 2015. Perbandingan laju pertumbuhan spirulina platensispada temperatur yang berbeda dalam skala laboratorium. Diponegoro Journal of Maquares Vol. 4 No. 1

Chaisutyakorn P, Praiboon J, Kaewsuralikhit C. 2017. The effect of temperature on growth and lipid and fatty acid composition on marine microalgae used for biodiesel production. J Appl Phycol 10.1007/s10811-017-1186-3

Christiani C, Insan AI, Hidayah HA. 2017. Pertumbuhan mikroalga hasil budidaya skala laboratorium dengan media kultur limbah cair tapioka. Prosiding Seminar Nasional, 7 pp. 17-18

Converti A, Casazza AA, Ortiz EY, Perego P, Borghi MD. 2009. Effect of temperature and nitrogen concentration on the growth and lipid content of Nannochloropsis oculata and Chlorella vulgaris for biodiesel production. Chemical Engineering and Processing 48 (2009) 1146-1151

Eda H. 1989. Summary of Research Activities on the Field of Rearing Technology of Larvae During the Period of April 24, 1989 to April 23, 1991. Japan Internasional Coorperation Agency

Endrawati H, Riniatsih I. 2013. Kadar Total Lipid Mikroalga Nannochloropsis oculata yang Dikultur dengan Suhu yang Berbeda. Buletin Oseanografi Marine Vol. 2(1): 25-33

Fogg GE, Thake B. 1987. Algae cultures and Phytoplankton Ecology, 3rd ed. Wisconsin, University Wisconsin Press, Madison didalam Hadiyanto dan Azim M. 2012. Mikroalga Sumber Pangan Dan Energi Masa Depan Edisi Pertama. Semarang: UPT UNDIP Press Semarang. $127 \mathrm{hlm}$
Guillard RRL. 1973. Divison rates in handbook of phycological methods: culture methods and growth measurement. Cambridge University Press

Halac SR, Villafane VE, Helbling EW. 2010. Temperature benefits the photosynthetic performance of the diatoms Chaetoceros gracilis and Thalassiosira weissflogii when exposed to UVR. Journal of Photochemistry and Photobiology B: Biology 101 (2010) 196-205

Handayani NA, Ariyanti D. 2012. Potensi Mikroalga sebagai Sumber Biomasa dan Pengembangan Produk Turunannya. Jurnal Teknik Vol. 33 No.2: 5865 .

Haris F. 2012. Pengaruh Perbedaan Suhu terhadap Pertumbuhan Mikroalga Scenedesmus sp. yang Dibudidayakan pada Limbah cair Tapioka [skripsi]. Malang: Universitas Islam Negeri: Hlm: 1-63

Hemalatha A, Karthikeyan P, Manimaran K, Anantharaman P, Sampathkumar P. 2012. Effect of Temperature on the Growth of Marine Diatom, Chaetoceros simplex (Ostenfeld, 1901) with Different Nitrate: Silicate Concentrations. Asian Pacific Journal of Tropical Biomedicine S1817S1821

Ihsan EN, Enita SY, Kunarso dan Wirasatriya A. 2017. Oceanographic factors in fishing ground location of anchovy at teluk cenderawasih national park, west papua: are these factors have an effect of Whale Sharks appearance frequencies. IOP Conference Series: Earth and Environmental Science 116 (2018) 012017. doi:10.1088/1755-1315/116/1/012017

Kawaroe M, Prartono T, Sunuddin A, Sari DW, Augustine D. 2010. Mikroalga: potensi dan pemanfaatannya untuk produksi bio bahan bakar. Bogor: PT. Penerbit IPB Press. $150 \mathrm{hlm}$.

Kurniawan MH, Sriati, Agung MUK, Mulyani Y. 2017. Pemanfaatan Skeletonema sp. dalam mereduksi limbah minyak solar di perairan. Jurnal Perikanan dan Kelautan Vol. 8 No. 2

LeGresley M, McDermott G. 2010. Counting chamber methods for quantitative phytoplankton analysis-haemocytometer, Palmer-Maloney cell and Sedgewick-Rafter cell. UNESCO: IOC Manuals and Guides 25-30

Likun W, Xuxiong H, Zhengzheng H. 2014. Temperature effects on lipid properties of microalgae Tetraselmis subcordiformis and Nannochloropsis oculata as Biofuel Resources. Chinese Journal of Oceanology and Limnology: 99-106

Mata TM, Martins AA, Caetano NS. 2009. Microalgae for Biodiesel Production and other Applications: A Review. Elsevier 217-232

Mortensen SH, Borsheim KY, Rainuzzo JR, Knutsen G. 1988. Fatty acid and elemental composition of the marine diatom Chaetoceros gracilis Schiitt. Effects of silicate deprivation, temperature and light intensity. Journal of Experimental Marine Biology and Ecology. Vol. 122, 173-185

Nagao R, Ueno Y, Akimoto S, Shen JR. 2020. Effects of $\mathrm{CO}_{2}$ and temperature on photosynthetic performance in the diatom Chaetoceros gracilis. Photosynthesis Research 10.1007/s11120-020-00729-8

Nhu CV. 2004. A Comparison of Yield and Quality of the Rotifer (Brachionus plicatilis - L-strain) Fed Different Diets Under Aquaculture Conditions, Vietnam. Asian Fisheries Science 17 (2004): 357-363

Ningsih DR, Widiastuti EL, Murwani S, Tugiyono. 2017. Kadar lipid tiga jenis mikroalga pada salinitas yang berbeda. Jurnal Biologi Eksperimen dan Keanekaragaman Hayati Vol. 4 No. 1

Octhreeani AM, Supriharyono, Soedarsono P. 2014. Pengaruh Perbedaan Jenis Pupuk Terhadap Pertumbuhan Nannochloropsis Sp. Dilihat dari Kepadatan Sel dan Klorofil-a pada Skala Semi Massal. Diponegoro Journal of Maquares Vol. 3 No 2

Pacheco MM, Hoeltz M, Moraes MSA, Schneider RCS. 2015. Microalgae: Cultivation techniques and wastewater phycoremediation. Journal of Environmental Science and Health, Part A 50, 573-589

Pangabean LMG. 2007. Koleksi Kultur Mikroalga. Oseana, Vol. 32, No. 2

Parrish CC, Wangersky PJ. 1990. Growth and lipid class composition of the marine diatom, Chaetoceros gracilis, in laboratory and mass culture turbidostats. Journal of Plankton Research Vol.12 No.5

Prayitno J. 2016. Pola pertumbuhan dan pemanenan biomassa dalam fotobioreaktor mikroalga untuk penangkapan karbon. Jurnal Teknologi Lingkungan Vol. 17 No.1

Rai SV, Rajashekhar M. 2014. Effect of pH, salinity and temperature on the growth of six species of marine phytoplankton. Journal of Algal Biomass Utilization 5 (4): 55-59 
Randrianarison G, Asraf MA. 2017. Microlagae: a Potensial plant for Energy Productions. Geology, Ecology, and Landscape 104-120

Ras M, Steyer JP, Bernard O. 2013. Temperature effect on microalgae: a crucial factor for outdoor production. Reviews in Environmental Science and Bio/Technology. 153-164

Renaud SM, Thinh LV, Lambrinidis G, Parry DL. 2001. Effect of temperature on growth, chemical composition and fatty acid composition of tropical Australian microalgae grown in batch cultures. Aquaculture 211 (2002) 195-214

Rudiyanti S. 2011. Pertumbuhan Skeletonema costatum pada berbagai tingkat salinitas media. Jurnal Saintek Perikanan Vol. 6 No. 2

Rukmana S, Hamzah M, Balubi AM, Iba W, Kurnia A. 2017. Pengaruh Pemberian Pakan Jenis Mikroalga yang Berbeda terhadap Tingkat Konsumsi Pakan dan Tingkat Kelangsungan Hidup Protozoea Udang Vaname (Litopenaeus vannamei). Media Akuatika, Vol.2 No.1: 328-336

Sartika, Mukarlina, Rima T, Setyawati. 2014. Kandungan klorofil dan lipid Nannochloropsis oculata yang dikultur dalam media limbah cair karet. Protobiont Vol. 3(3): 25-30

Schutt.

1895

http://www.marinespecies.org/aphia.php?p=taxdetails\&id=178204.

diakses pada 30 Oktober 2019

Sheehan J, Dunahay T, Benemann J, Roessler P. 1998. A Look Back at the U.S. Department of Energy's Aquatic Species Program-Biodiesel from Algae. U.S. Department of Energy's Office of Fuels Development

Suantika G, Hendrawandi D. 2009. Efektivitas teknik kultur menggunakan sistem kultur statis, semi-kontinyu, dan kontinyu terhadap produktivitas dan kualitas kultur Spirulina sp. Jurnal Matematika dan Sains. Vol. 14: 4150

Tokushima H, Inoue-Kashino N, Nakazato Y, Masuda A, Ifuku K, Kashino Y. 2016. Advantageous characteristics of the diatom Chaetoceros gracilis as a sustainable biofuel producer. Biotechnology for Biofuels: 9:235

Wahjuni S. 2013. Metabolisme Biokimia. Denpasar: Udayana University Press. $102 \mathrm{hlm}$ 